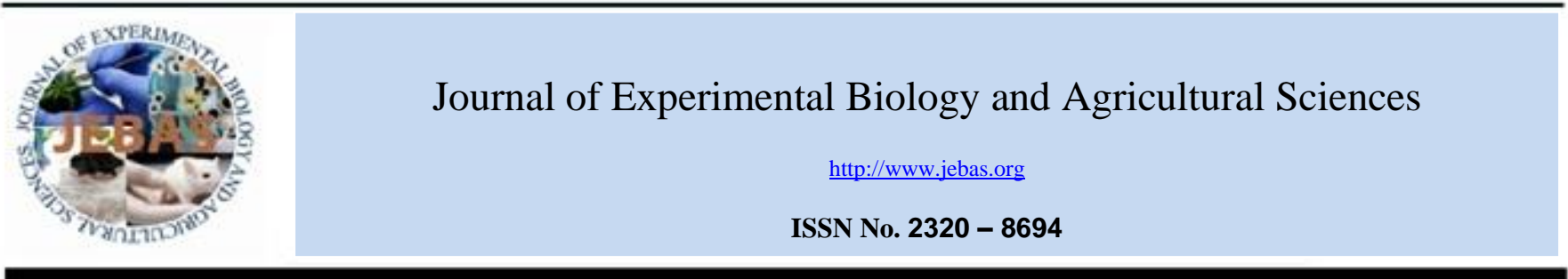

\title{
PHYTOCHEMISTRY AND PHARMACEUTICAL EVALUATION OF Balanites aegyptiaca: AN OVERVIEW
}

\author{
Saed A. Al-Thobaiti*, Isam M. Abu Zeid \\ Department of Biological Sciences, Faculty of Sciences, King Abdulaziz University, P.O. Box 139109, Jeddah 21323, Saudi Arabia. \\ Received - April 11, 2018; Revision - May 24, 2018; Accepted - June 11, 2018 \\ Available Online - June 20, 2018
}

DOI: http://dx.doi.org/10.18006/2018.6(3).453.465

\section{KEYWORDS}

Balanites aegyptiaca

Bioactive Compounds

Secondary Metabolites

Folkloric Medicine and

Therapeutic Activity.

\begin{abstract}
Balanites aegyptiaca, is one of the awfully potent neglected wild plant species found mainly in both African and South Asian deserts. It is a historical and elegant folkloric medicinal plant due to its curative nature towards diverse fatal diseases, it is conventionally utilized in management of a variety of ailments such as jaundice, intestinal worm infection, wound healings, malaria, syphilis, epilepsy, dysentery, stomach aches, constipation, diarrhea, haemorrhoid and asthma. Biochemical analysis of plant extract revealed the presence of carbohydrates, lipids, proteins, alkaloids, flavonoids, saponins and organic acids. Due to the presence of these active ingredients, it is served as antioxidant, antihelminthic, antimicrobial (mainly the fixed oil) immunostimulant, anticarcinogenic, antidiabetic, contraceptive antifeedant, antiviral and molluscicidal activities. In conclusion, this review explored the presence of various secondary metabolites from various plant parts of Balanites aegyptiaca.
\end{abstract}

* Corresponding author

E-mail: saiad1402@gmail.com (Saed A. Al-Thobaiti)

Peer review under responsibility of Journal of Experimental Biology and Agricultural Sciences.

Production and Hosting by Horizon Publisher India [HPI] (http://www.horizonpublisherindia.in/).

All rights reserved.
All the article published by Journal of Experimental Biology and Agricultural Sciences is licensed under a Creative Commons Attribution-NonCommercial 4.0 International License Based on a work at www.jebas.org.

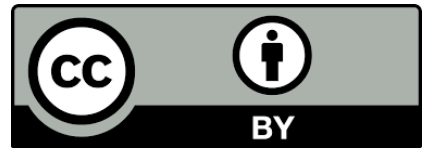




\section{Introduction}

Balanites aegyptiaca (L.) Delile, a drought-tolerant perennial tropical ever green tree belongs to family Zygophyllaceae (Balanitaceae), is commonly known as 'desert date' (Heiglige in Arabia) (Hall \& Waljer, 1991). The name Balanites originally derived from the Greek word which means fruit resemble acorn (Gupta et al., 2012). It is also known by different vernacular names such as as Angarvriksha, Balanite, Desert date, Bedeno, Hingot, Soapberry tree, Thorn tree and Egyptian balsam and many more (Rathore et al., 2005). It is native to arid and sub arid part of Africal and Middle East especially Arabian Peninsula (Arboneir, 2004) but most widely in various parts of Africa and South Asia (Hall \& Waljer 1991; Ndoye et al., 2004; Hammouda et al., 2005; Okia et al 2011; Chothani \& Vaghasiya, 2011; Al-Thobaiti \& Abu Zeid, 2018). Presence of tree is well reported from India, Iran, Pakistan (Amalraj \& Shankarnarayan, 1998), Sudan (Grosskinsky \& Gullick, 2001), Nigeria (Lockett et al., 2000), Ethiopia, (Guinand \& Lemessa, 2001; Aregay et al., 2017), Ghana (Augustus et al., 2014), and Burkina Faso (Sourabie et al., 2013).

It can be grow in various habitat, soil types and climatic conditions (Varshney \& Vyas, 1982; Sarker et al., 2000; Pandey, 2005). Also, the tree has good adaptive mechanisms to grow and thrive under combined water and salinity stresses (Maksoud \& ElHadidi, 1988). It is a multi branched, thorny, shrub or tree which reached upto $10 \mathrm{~m}$ in height (Yadav \& Panghal, 2010; Chothani \& Vaghasiya, 2011). In the month of October, the tree has inflorescence bearing yellow-green bisexual flowers which exude nectar.

B. aegyptiaca is multipurpose tree and used for food and fodder in almost all parts of Africa and South Asia (Elseed et al., 2002; Billore, 1988). Among the various plant parts, fleshy pulp of the fruit is eaten fresh or dried. It also used as a food, beverage, \& medicines (National Research Council, 2008). In protein content, this fruit is superior than banana, guava, mango and papaya. Fleshy fruit contains $64-72 \%$ carbohydrates, crude protein, steroidal saponins (Dawidar \& Fayez, 1969), vitamin A, vitamin $\mathrm{C}$ and other essential minerals for human. Seed kernel also widely used for oil. The kernel produces high quality edible oil (Obidah et al., 2009) with large number of medicinal properties (Hanan et al., 2009). The kernel is also rich in protein and minerals contents (Elfeel \& Warrag, 2011). In quality aspect, it is similar to sesame and groundnuts oils (Abu Al-Futuh, 1983; Obidah et al., 2009). Seed also used for biodiesel production (Chapagain et al., 2009; Gutti et al., 2012; Kumawat et al., 2012).

Different parts of B. aegyptiaca have several bioactive substances which possess miscellaneous medicinal properties. A bioactive substance is defined as a constituent possessing an effect on causes of a reaction, or trigger of a response in the living tissue
(Abdelkarim et al., 2014). The bark, fruit and oil of tree have been widely used to treat various disease or disorders such as cancer (Gnoula et al., 2008; Hassan et al., 2016; Montasser et al., 2017), tuberculosis (Hassan et al., 2016), HIV/AIDS (Sheded et al., 2006; Alashaal et al., 2010), malaria (Kusch et al., 2011; Bobbo et al., 2016; Sibhat \& Hiben, 2016), diabetes (Helal et al., 2013; Abou Khalil et al., 2016), sleeping sickness (Barley, 1962; Sheded et al., 2006; Alashaal et al., 2010), wounds (Chevallier et al., 2003; Kommu et al., 2013), colds, syphilis, liver and spleen disorders (Abdel-Kader et al., 2008; Zaahkouk et al., 2015), jaundice (Sarker et al., 2000; Abdulmalik et al., 2011), yellow fever, snake bite (Ojo et al., 2006) and aches (Mohamed et al., 1999; Hamid et al., 2001). The infusion of root bark has been used in diarrhoea, haemorrhoid and also acts as a fish poison (Bukar et al., 2004).

B. aegyptiaca fruits have various primary and secondary metabolites such as flavonoids, furanocoumarin, saponins, fixed oil protein, fat, carbohydrates and vitamin C. Along with this it has various electrolytes or minerals such as calcium ions, iron, magnesium, phosphorus, zinc, copper and potassium ions (Stadlmayr et al., 2013). Among the identified secondary metabolites, anticancer or anti tumors properties of Balanitin and saponins has been well reported by various researchers (Gnoula et al., 2008; Hassan et al., 2016)

\section{Objective of Review}

This review focus on the ethnopharmacological potential and phytochemicals present in different parts of $B$. aegyptiaca with beneficial health effects. Though already some information are available on the phytochemical constitution of B. aegyptiaca and its effect on human health but up-to-date and critical information on the plant with respect to its ethnopharmacology and phytopharmaceutical potential is scanty and not well-documented. Therefore, this review has been written on various aspects of ethnopharmacology and phytochemistry of B. aegyptiaca.

\section{Phytochemical Constituents of B. aegyptiaca}

B. aegyptiaca have been investigated chemically for various classes of constituents. It is reported to contain a number of secondary metabolites and bioactive compounds (Figure 1-4), including flavonoides, alkaloid, glucosides, phenolic, steroids saponins, furanocoumarins, Diosgenin, N-trans-feruloyltyramine, $\mathrm{N}$-cis-feruloyltyramine, trigonelline, balanitol, fatty acid (Speroni et al., 2005).

\subsection{Flavonoids}

Flavonoids consist of two aromatic carbon rings viz., benzene and benzopyran, based on the arrangement of carbon ring oxidation degree (Spencer, 2008). Presence of the various class of 
flavonoids has been reported from the B. aegyptiacac, among these some important classes of flavonoids viz., quercetin-3rutinoside, quercetin 3-glucoside, 3-glucoside, 3-rutinoside, 3-7diglucoside and 3-rhamnogalactoside of isorhamnetin have been extracted from the leaves and fruit of the B. aegyptiaca (Maksoud \& El-Hadidi, 1988; Sarker et al., 2000). Speroni et al. (2005) have been identified the presence of Isorhamnetin-3-O-robinobioside from all parts of B. aegyptiaca. B. Flavonoids have considerable role in tumour and chronic disease treatment and also have antimicrobial properties (Salwa et al., 1988; Samuelsson et al., 1991; Kamel, 1998, Speroni et al., 2005).

\subsection{Alkaloids Compounds}

B. aegyptiaca bark contains various alkaloids such as N-transferuloyltyramine and N-cisferuloyltyramine. Presence of the alkaloids has been also reported from the seeds and oil. Role of $\mathrm{N}$-trans-feruloyltyramine in cancer treatment have been well studied by various researchers (Sarker et al., 2000).

\subsection{Steroidal Glycosides}

Farid et al. (2002) isolated five steroidal glycosides viz., $(3 \beta, 12 \alpha, 14 \beta, 16 \beta)$-12-hydroxycholest-5-ene-3, 16-diyl bis( $\beta$-D-glucopyranoside $) \quad, \quad(3 \beta, 20 \mathrm{~S}, 22 \mathrm{R}, 25 \mathrm{R})-\quad$ and (3ß,20S,22R,25S)-26-( $\beta$-D-glucopyranosyloxy)-22-methoxyfurost-5en-3-yl

$\beta$-D-xylopyranosyl-( $(1 \rightarrow 3)$ - $\beta$-D-glucopyranosyl-( $(1 \rightarrow 4)[\alpha-L-$-rhamnop yranosyl-( $(1 \rightarrow 2)]-\beta$-D-glucopyranoside, $\quad(3 \beta, 20 \mathrm{~S}, 22 \mathrm{R}, 25 \mathrm{R})-\quad$ and $(3 \beta, 20 \mathrm{~S}, 22 \mathrm{R}, 25 \mathrm{~S})$-spirost-5-en-3-yl

$\beta$-D-xylopyranosyl-( $1 \rightarrow 3)$ - $\beta$-D-glucopyranosyl- $(1 \rightarrow 4)[\alpha$-L-rhamnop yranosyl-( $(1 \rightarrow 2)]$ - $\beta$-D-glucopyranoside from $B$. aegyptiaca roots (Hostettmann \& Marston, 1995).

Presences of various types of saponins have been reported from $B$. aegyptiaca crude extract. Saponins are complex association of glycosides (Sugar residues) and sapogenin (aglycone part of 2731 carbon atoms as steroid or a triterpene). Major steroidal saponins which have been reported from bark and root of $B$. aegyptiaca are balanitin -1, 2, 3, 4, 5, 6 and 7 (Hardman \& Sofowora, 1970; Morsy, 2008; Gnoula et al., 2008). Recently saponins proved to have wide range of medicinal properties such as anticancer or antitumor (Gnoula et al., 2008), antiinflammatory properties, inhibitory effect on HIV, antioxidant activity (Ali et al., 2012), effective antischistosomal remedy (Koko et al., 2005), and mosquito control (Wiesman \& Chapagain, 2003).

Diosgenin is a type of sapogenin compound which have been isolated from seed, leaves and fruit of B. aegyptiaca, and can be used as natural source of steroidal hormones (FAO, 1985; Pettit et al., 1991; Farid et al., 2002). According to Beneytout et al. (1995) and Nappez et al. (1995) diosgenin is responsible for morphological and biochemical changes in megakaryocyte cells. Hosny et al. (1992) reported the presence of 6-methyl diosgenin from the fruit of B. aegyptiaca.

Preliminary phytochemical investigations revealed that $B$. aegyptiaca possessed various classes of glycosides such as cardiac glycosides, Balanitoside, Pregn-5-ene-3 $\beta, 16 \beta, 20(\mathrm{R})$-triol 3-O- $\beta$-dglucopyranoside and 26-(O- $\beta$-D-glucopyranosyl)-3- $\beta$-[4-O( $\beta$-D-glucopyranosyl)-2-O-( $\alpha$-L-rhamnopyranosyl)- $\beta$-D-glucopyra nosyloxy]-22,26-dihydroxyfurost-5-ene (Kamel \& Koskinen 1995; Speroni et al., 2005; Staerk et al., 2006; Al Ashaal et al., 2010; Chothani \& Vaghasiya, 2011). The roots and bark also contain yamogenin which is a glycone with a branched glucose and rhamnose side chain (Speroni et al., 2005). These phytochemicals may be responsible for the treating certain skin infections, heart disease and diabetes (Chothani \& Vaghasiya, 2011). Yamogenin have properties to cure hepatic steatosis, diabetic mellitus and obesity (Speroni et al., 2005).

\subsection{Glucosides}

The leaves, fruit, bark and kernels of B. aegyptiaca were found to contain various class of glucosides including 2Diglucosyldirhamnoside, beta-sitosterol, di-, tri-, and tetraglucosides. These glucosides are responsible for the antidiabtic and antimicrobial properties of the tree extract (Varshncy \& Vyas (1982); Saeed et al., 1995; Kapseu et al., 1997; Ansari et al. 2006; Breimer et al., 2007).

\subsection{Phenolic Compounds}

The bioactive constituent's phenols are reported from seeds and bark of B. aegyptiaca. Most commonly reported phenolic compounds are 2,4-di-tertbutyl-phenol, 2,6-di-tert-butyl-phenol (seed), 3-hydroxy-1-(4-hydroxy-3- methoxyphenyl)-1-propanone, syringic acid, vanillic acid and Coumarins (bark). These phenolic compounds have antimalarial, antioxidant, anti-diabetic, antiinflammatory, anti-tumor, enzyme inhibitory antifungal, antimicrobial and antiviral, activity (Sarker et al., 2000; Kusch et al., 2011; Rohini \& Srikumar, 2014).

\subsection{Fatty Acid}

The seed oil of B. aegyptiaca is good and edible quality with highest percentage of Fatty acids. The oil contains mainly palmitic, stearic, oleic, and linoleic acids which were the main 
fatty acids (Zang et al., 2017). Presence of Omega-3 and Omega-6 Essential Fatty Acids from kernel seed oil has been reported by Elhardallou et al. (2014). The oil exhibited anticancer activity against lung, liver, and brain human carcinoma cell lines. It also had antimutagenic, antiviral and antimicrobial activities against the selected microorganisms.

\subsection{Other Compounds}

In addition to the above phytochemicals, presence of 1-10-methyln-heptacosane (Ansari et al., 2006), balanitol (Cordano et al.,
1978), bergapten (Seida et al., 1981; Breimer et al., 2007), cryptogenin, deltoin (Speroni et al., 2005), furanocoumarin (Khare 2007) and marmesin (Ansari et al. 2006; Breimer et al., 2007 ) has been reported from the bark of B. aegyptiaca. Presence of Protodeltoin (Speroni et al., 2005) and 6-phenyl-2(H)-1,2,4triazin-5-one oxime (Kusch et al., 2011) has been reported from the seed of B. aegyptiaca. These chemicals also have antioxidants, antimalarial, anti-inflammatory and antidiabtic properties (Speroni et al., 2005; Ansari et al. 2006; Breimer et al., 2007; Kusch et al., 2011). Psoriasis treatment capability of bergapten has been reported by Ansari et al. (2006) and Breimer et al. (2007).<smiles>CC(C)(C)c1cccc(C(C)(C)C)c1O</smiles>

2,6-di-tert-butyl-phenol

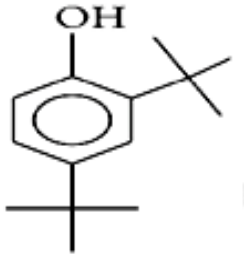

2,4-di-tertbutyl-phenol<smiles>COc1cc(C(=O)O)cc(OC)c1O</smiles>

Syringic acid<smiles>COc1cc(C(=O)O)ccc1O</smiles>

Vanillic acid<smiles>COc1cc(C(=O)CCO)cc(OC)c1O</smiles>

3-hydroxy-1-(4-hydroxy-3methoxyphenyl)-1-propanone<smiles>O=c1ccc2ccccc2o1</smiles>

Coumarins<smiles>C[C@H]1CC[C@@H](O)[C@]2(C)CC[C@@H](C(C)(C)O)C[C@@H]12</smiles>

Balanitol<smiles>CCC1CCC(CCC(C)[C@@H](C)[C@H](C)C(C)C2CCC(CC)C(CC)C2)CC1</smiles>

N-cis-feruloyltyramine

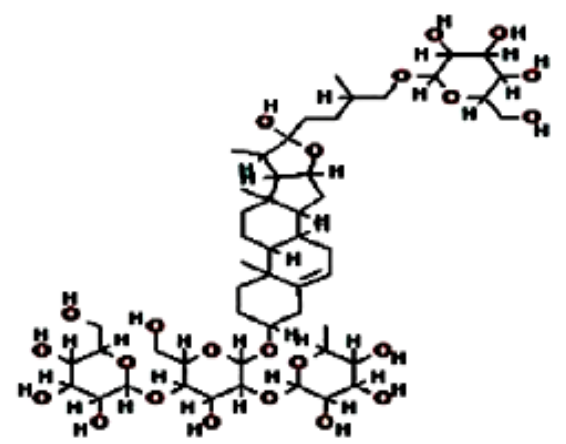

Balanitoside<smiles>COc1cc(C=CC(=O)NCCc2ccc(O)cc2)ccc1O</smiles>

N-trans-Feruloyltyramine

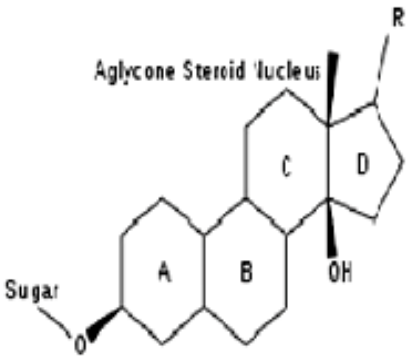

Cardiac glycosides

Figure 1 Chemical identified and isolated from Balanites aegyptiaca 
<smiles>C[C@H]1CC[C@]2(OC1)O[C@H]1C[C@H]3[C@@H]4CC=C5C[C@@H](O)CC[C@]5(C)[C@H]4CC[C@]3(C)[C@H]1[C@H]2C</smiles>

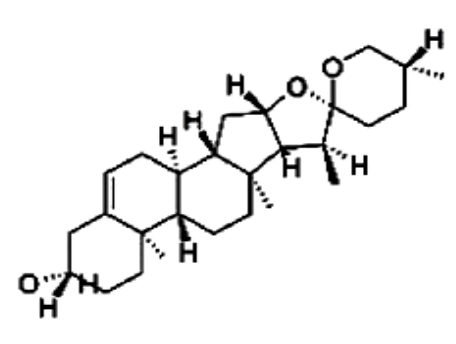

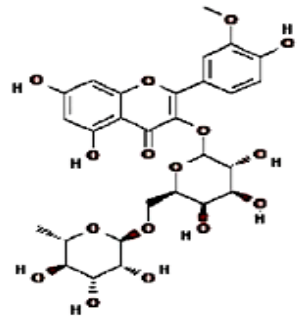<smiles>CC1O[C@H](OC[C@H]2O[C@H](Oc3c(-c4ccc(O)c(O)c4)oc4cc(O)cc(O)c4c3=O)[C@H](O)[C@H](O)[C@H]2O)[C@H](O)[C@@H](O)[C@@H]1O</smiles><smiles>O=c1c(O[C@@H]2O[C@H](CO)[C@@H](O)[C@H](O)[C@H]2O)c(-c2ccc(O)c(O)c2)oc2cc(O)cc(O)c12</smiles>

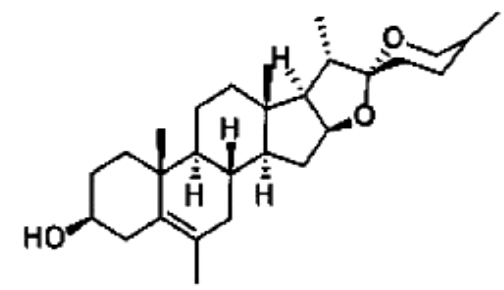

Quercetin-3-rutinoside

Quercetin 3-glucoside

6-Methyl diosgenin

Figure 2 Chemical identified and isolated from Balanites aegyptiaca

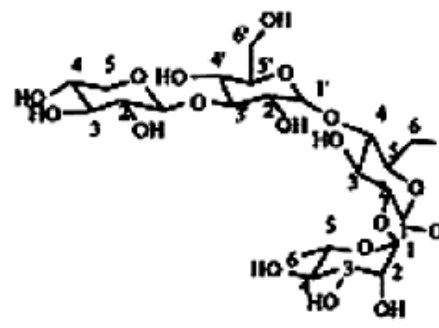

Balanitin-2

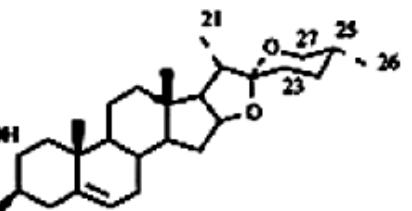
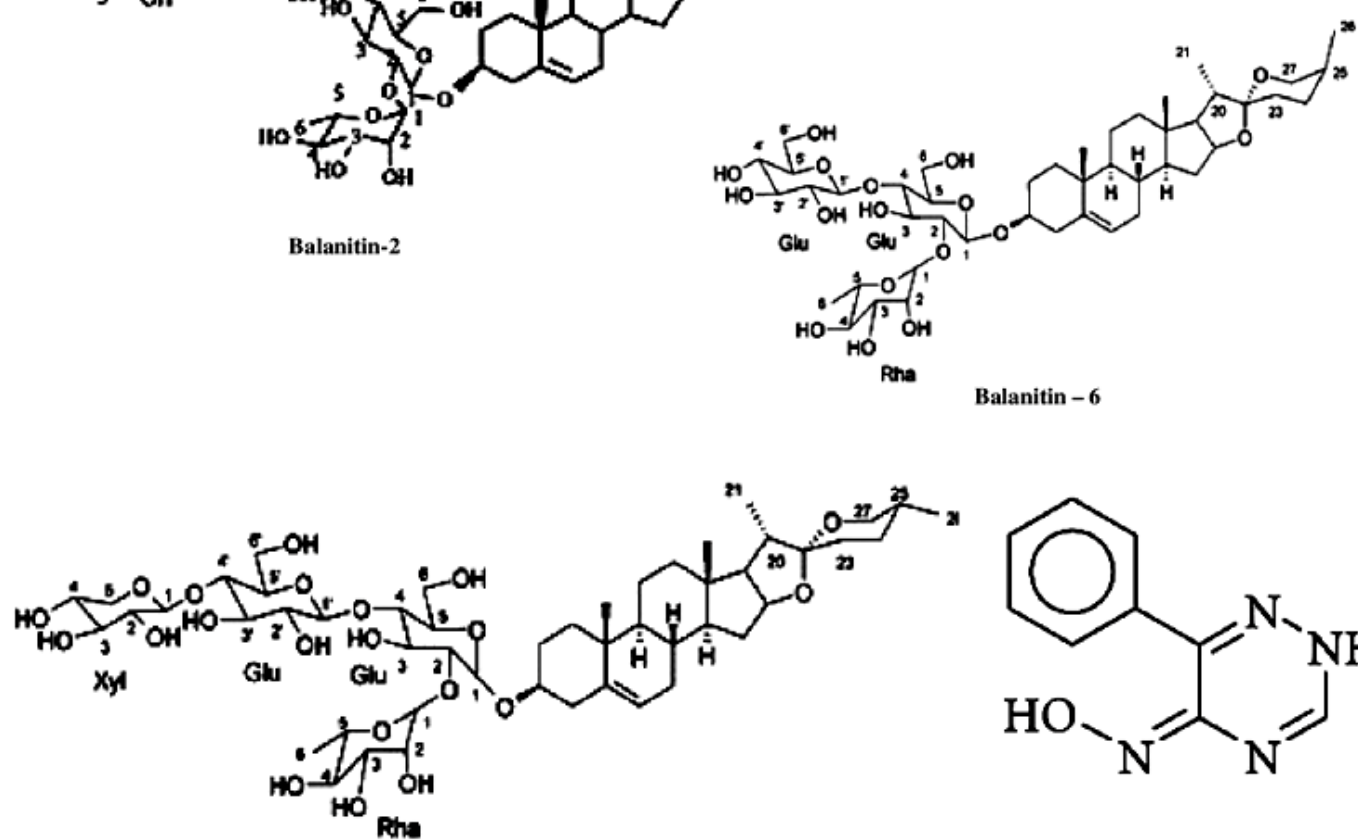<smiles>O/N=c1/nc[nH]nc1-c1ccccc1</smiles>

Balanitin - 7

6-phenyl-2(H)-1,2,4-triazin-5-one oxime

Figure 3 Chemical identified and isolated from Balanites aegyptiaca 
<smiles>COc1c2ccoc2cc2oc(=O)ccc12</smiles>

Bergapten<smiles>CC(C)(C)c1cccc(C(C)(C)C)c1O</smiles>

2,4-di-tertbutyl-phenol<smiles>CC=C(C)C(=O)OC(C)(C)[C@@H]1Cc2cc3ccc(=O)oc3cc2O1</smiles>

Deltoin<smiles>CC(C)(O)[C@@H]1Cc2cc3ccc(=O)oc3cc2O1</smiles>

Marmesin

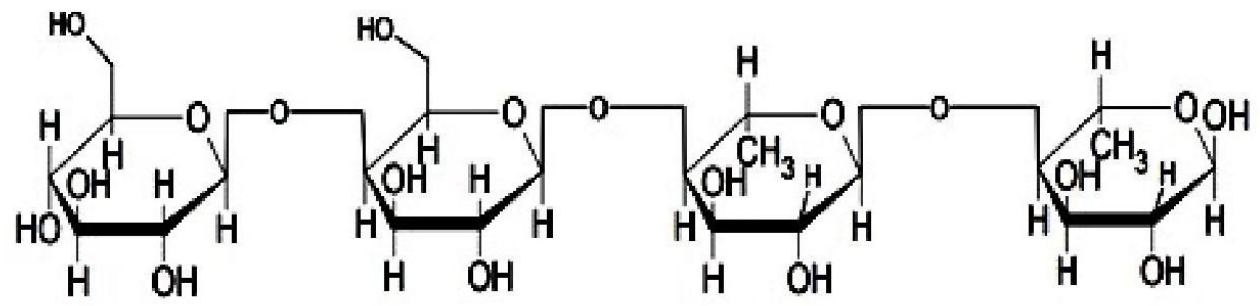

\section{2- Diglucosyldirhamnoside}

Figure 4 Chemical identified and isolated from Balanites aegyptiaca

\section{Pharmacological Aspects of Isolated metabolites}

B. aegyptiaca have been a valuable source of natural active constituents of products that maintain human health and in the treatment of many human diseases (Table 1). It is widely used in African (Sudan, Ethiopia, Nigeria, Senegal, Chad, Egypt) and Asian countries. Flavonoids is a major constitute of tree bark, root and stem and it exhibited in vitro antioxidant potential (RiceEvans et al., 1996). Further, furanocoumarins which have been isolated from the various parts showed several biological activities such as anti-inflammatory, antioxidant, anti-neoplastic as well as bone health preservation both in vitro and in vivo. Further, furanocoumarins wielded antiproliferative activities against cancer cell growth through several molecular pathway modulation, such as regulation of the signal transducer and activator of phosphatidylinositol-3-kinase/AKT, nuclear factor$\mathrm{kB}$, and mitogen-activated protein kinase expression (Hung et al., 2016). 5-Methoxypsoralen, also known as bergapten, is a linear furanocoumarin that occurs naturally and has been used to control vitiligo and psoriasis (Seida et al., 1981; McNeely \& Goa, 1998).
Saponins are triterpenoid glycosides or steroid that has hypocholesterolaemic, anticarcinogenic and immunostimulant properties (Francis et al., 2007). A significantly high inhibitory activity against hyperglycemia was expressed only from the furostanol saponin as it successfully inhibited $\alpha$-glucosidase and aldose reductase, showing that these $\alpha$-glucosidase (AG) inhibitors are responsible for reversibly delaying the absorption of glucose from the gastrointestinal tract (Campbell et al., 1996; Yabe-Nishimura, 1998; Saharan et al., 2008; Abdel Motaal et al., 2015). Similarly, anti-hyperglycemic properties of B. aegyptiaca fruit have been reported by Farag et al. (2015), these researchers reported that this antihyperglycemic properties may be because of the presence of trigonelline; a pyridine containing alkaloids. Trigonelline acts by affecting cell regeneration, insulin secretion, enzymes affecting glucose metabolism, and diminishes the oxidative stress in type 2 diabetes (Amaro et al., 2014).

The extracted oil from B. aegyptiaca inhibited human cancer cell line growth and had anticancer activity against brain, liver and lung carcinoma cell lines (Al Ashaal et al., 2010; Chothani \& 
Table 1 Therapeutic use of various plant parts of B. Aegyptiaca against various diseases

\begin{tabular}{|c|c|c|}
\hline Plant Part & Cured Diseases & References \\
\hline Complete Plant & $\begin{array}{l}\text { Jaundice, anthelmintic, rheumatism, CNS depressant, fungicidal, } \\
\text { larvicidal, molluscicidal, insecticidal properties, it also used to } \\
\text { remove intestinal parasites }\end{array}$ & $\begin{array}{l}\text { Neuwinger, 1996; Mohamed et al., 1999, Koko et al., } \\
\text { 2000; Koko et al., 2005; Wiesman \& Chapagain, } \\
\text { 2006; Chapagain et al., 2009; Patil et al., 2010; } \\
\text { Abdulmalik et al., 2011; Shalaby et al., 2012 }\end{array}$ \\
\hline Stem/Root Bark & $\begin{array}{l}\text { Yellow fever, jaundice, antiangiogenic, antitumor, antioxidant, } \\
\text { antimalarial, anti trypanocidal activity, cytotoxicity, mental } \\
\text { diseases, diarrhea, epilepsy, treatment of Syphilis round worm } \\
\text { infection, haemorrhoid, fish poison, antivinom against viper } \\
\text { venom and syphilis }\end{array}$ & $\begin{array}{l}\text { Bukar et al., 2004; Katewa et al., 2004; Wurochekke } \\
\text { \& Nok, 2004; Koch et al., 2005; Gad et al., 2006; Ojo } \\
\text { et al., 2006; Wufem et al., 2007; Ahmad Hassan et } \\
\text { al., } 2016\end{array}$ \\
\hline Fruit & $\begin{array}{l}\text { Skin diseases, sleeping sickness, oral hypoglycemia, } \\
\text { cytotoxicity, antitumor effects, antioxidant, antifertility, } \\
\text { insecticidal activity, anticonvulsant effect, cure mouth ulcer, } \\
\text { boils and burns, whooping cough, effective antischistosomal } \\
\text { remedy, act as an antidote to arrow poison }\end{array}$ & $\begin{array}{l}\text { Rao et al., 1997; Wiesman \& Chapagain, 2003; } \\
\text { Katewa et al., 2004; Koch et al., 2005; Koko et al., } \\
\text { 2005; Gad et al., 2006; Ojo et al., 2006; Gnoula et al., } \\
\text { 2008; Thirupathi et al., 2009; Al-Ghannam et al., } \\
\text { 2013; Molla et al., 2013; Wabale, } 2017\end{array}$ \\
\hline Seed & $\begin{array}{l}\text { Antitumor, anti-cancer antibacterial, antioxidant, antimalarial } \\
\text { activity, effective antischistosomal remedy and cure cough, colic } \\
\text { pain }\end{array}$ & $\begin{array}{l}\text { Wiesman \& Chapagain, 2003; Bukar et al., 2004; } \\
\text { Koko et al., 2005; Ojo et al., 2006; Gnoula et al., } \\
\text { 2008; Kusch et al., 2011; Mostafa et al., } 2016\end{array}$ \\
\hline Seed oil & $\begin{array}{l}\text { Skin diseases, diabetes, hypoglycemia, sleeping sickness and } \\
\text { promising for HIV/AIDS patients }\end{array}$ & $\begin{array}{l}\text { Cook et al., 1998; Sheded et al., 2006; Alashaal et al., } \\
2010\end{array}$ \\
\hline Leaves & $\begin{array}{l}\text { Wound healing, curing anthrax, antihelminthic activities, to clean } \\
\text { malignant wounds }\end{array}$ & Ojo et al., 2006; Kommu et al., 2013 \\
\hline Root & $\begin{array}{l}\text { Stomach pain, anthrax, and the infusion of root also acts as an } \\
\text { antidote to snake bite }\end{array}$ & Ojo et al., 2006 \\
\hline
\end{tabular}

Vaghasiya, 2011). Presence of the B-sitosterols has been reported from the B. aegyptiaca extract, Wilt et al. (1999) reported antiinflammatory effects of this metabolite. Also, the presence of phytosterol, especially $\beta$-sitosterol articulated antioxidant and antineoplastic activity (Al Ashaal et al., 2010). The antimicrobial effects with stearic, oleic and linoleic acids in addition to $\beta$ sitosterol revealed with greatest inhibition against Candida albicans and Staphyloccous aureus when extract efficacy was compared with Tavanic and Nystatine as standards (Al Ashaal et al., 2010; Chothani \& Vaghasiya, 2011).

Further, Chaudhry \& Khoo (2004) reported antiviral activity of $B$. aegyptiaca plant against HIV/AIDS. Similarly, virucidal activity of B. aegyptiaca oil against Herpes simplex virus type 1 (HSV1) has been reported by Al Ashaal et al. (2010).

The fixed oil of $B$. aegyptiaca possesses anthelmintic activity against Schistosoma mansoni and Fasciola gigantica, it found equal effective to praziquantel which used as a positive control (Al Ashaal et al., 2010). Dose-dependent effect of B. aegyptiaca oil on micronuclei and chromosomal aberrations was also reported by Al Ashaal et al. (2010).

The methanolic and ethanolic extract of B. aegyptiaca leaves have diuretic effect when tested on Wistar albino rats against Frusemide as a standard (Wani et al., 2010). The methanolic extract of B. aegyptiaca fruits also proved as a cheap alternative of more expensive anthelmintics as it showed a potent and progressive effect on the cuticle of adult Toxocara vitulorum and an inhibitory effect on $T$. vitulorum egg development (Shalaby et al., 2012).

\section{Toxicology of Phytochemicals}

Discussions of the phytochemical and ethanopharmaceutical properties of $B$. aegyptiaca have established that this is a values plant for the traditional and modern medicine. Though drug obtained from plant have limited chances of side but sometime improper dose can cause adverse effect of humans. Therefore toxicological study of various phytochemicals is must, Mariam et al. (2013) studied the toxicological effect of B. aegyptiaca, and 
revealed that oral administration of the extract at the specified doses showed any toxicity on liver cells. Suky et al. (2011) studied acute toxicity of $200-2000 \mathrm{mg} / \mathrm{kg}$ ethanol extract of B. aegyptiaca and observed that extract did not have any behavioural changes or mortality even at a dose of $2000 \mathrm{mg} / \mathrm{kg}$ which indicate the safety of this extract. Similarly, Obidah et al. (2009) also studied the toxicological aspect of crude seed oil and suggested that crude oil did not result in marked changes in the toxicological parameters of experimental animal, which suggested that crude oil is edible and consumption of the crude oil at the present level of exposure may be of no serious safety concern, especially on liver and kidney injury. Findings of Absalom et al. (2013) are contradictory to the findings of previous two, these researchers investigate the toxic effects of $B$. aegyptiaca fruit extract on the mortality and behaviour of juveniles of African catfish (Clarias gariepinus) and reported that at higher concentration (64.0gL-1) fruit extract caused fish mortality, and its toxic effects lowered the values of some haematological parameters compared to the control group.

\section{Conclusions}

This review confirms the potential of B. aegyptiaca as traditional medicine and also established its antidiabetic, antiviral, antibiotic, anticancer, antihelminthic and molluscicidal activities . Presence of the flavonoids, terpenoids, steroids, alkaloids and saponins as an bioactive entities was also confirmed by this review article. Considerable outstanding activities of B. aegyptiaca, suggested by this review article generate the opportunity to precede detailed study on the mechanism of actions of these compounds with respect to feature aspects of molecular investigations.

\section{Conflict of interest}

All the authors declare that there is no conflict of interest.

\section{References}

Abdel Motaal A, El-Askary H, Crockett S, Kunert O, Sakr B, Shaker S, Bauer R (2015) Aldose reductase inhibition of a saponin-rich fraction and new furostanol saponin derivatives from Balanites aegyptiaca. International Journal of Phytotherapy and Phytopharmacology 22: 829-836.

Abdel-Kader MS, Alqasoumi SI (2008) Evaluation of the hepatoprotective effect of the ethanol extracts of Solanum nigrum, Cassia fistula, Balanites aegyptiaca and Carthamus tinctorius against experimentally induced liver injury in rats. Alexandria Journal of Pharmaceutical Sciences 22:47-50.

Abdelkarim G, Benaicha N, Elmajdoub M, Hamal A (2014) What is a bioactive compound? A combined definition for a preliminary consensus. International Journal of Nutrition and Food Sciences 3: 174-179.
Abdulmalik YJ, Yaro UN, Chindo AH, Anuka JA, Hussaini IM (2011) Behavioral Properties of Balanites aegyptiaca in Rodents. Journal of Ethnopharmacology 135: 725-729.

Abou Khalil NS, Abou-Elhamd AS, Wasfy SI, El Mileegy IM, Hamed MY, Ageely HM (2016) Antidiabetic and Antioxidant Impacts of Desert Date (Balanites aegyptiaca) and Parsley (Petroselinum sativum) Aqueous Extracts: Lessons from Experimental Rats. Journal of Diabetes Research 2016:8408326. doi: 10.1155/2016/8408326.

Absalom KV, Nwadiro PO, Wophill N (2013) Toxicity of Aqueous Extract of Desert Date (Balanites aegyptiaca Linnaeus) On the Juveniles of Catfish (Clarias Gariepinus Teugels, 1986). IOSR Journal of Agriculture and Veterinary Science 3: 13-18.

Abu-Al-Futuh IM (1983) Balanites aegyptiaca: An Unutilized raw material potential ready for agroindustrial exploitation. UNIDO Document no. 12419 project TF/INT/77/021. UNIDO of the United Nations.

Ahmed Hassan LE, Dahham SS, Mohammed Saghir SA, Mohammed AMA, Eltayeb NM, Abdul Majid AMS, Abdul Majid AS (2016) Chemotherapeutic potentials of the stem bark of Balanite aegyptiaca (L.) Delile: an antiangiogenic, antitumor and antioxidant agent. BMC Complementry \& Alternative Medicine 16: 396.

Al Ashaal H, Farghaly A, Abd El Aziz M, Ali M (2010) Phytochemical investigation and medicinal evaluation of fixed oil of Balanites aegyptiaca fruits (Balantiaceae). Journal of Ethnopharmacology 127: 495-501.

Al-Ghannam SM, Ahmed HH, Zein N, Zahran F (2013) Antitumor Activity of Balanitoside Extracted from Balanites aegyptiaca Fruit. Journal of Applied Pharmaceutical Science 3 : 179-191.

Ali R, Mirza Z, ASHRAF GM, Kamal MA, Ansari SA, Damanhouri GA, Abuzenadah AM, Chaudhary AG, Sheikh IA (2012) New anticancer agents: recent developments in tumor therapy. Anticancer Research 32 :2999-3005.

Al-Thobaiti S, Abu Zeid I (2018) Medicinal properties of desert date plants (Balanites aegyptiaca) an overview. Global Journal of Pharmacology 12: 1-12.

Amalraj VA, Shankanarayan KA (1998) Ecological distribution of Balanites roxburghii $\mathrm{pl}$ in arid Rajasthan. Journal of Tropical Forest Science 2: 183-187.

Amaro C, González-Cortazar M, Herrera-Ruiz M, Román-Ramos R, Aguilar-Santamaría L, Tortoriello J, Jiménez-Ferrer E (2014) 
Hypoglycemic and hypotensive activity of a root extract of Smilax aristolochiifolia, standardized on N-trans-feruloyl-tyramine. Molecules 19: 11366-11384.

Ansari MM, Ahmad J, Ali M, Ansari SH (2006) 10-Methyl-nheptacosane and diglucosyldirhamnoside from the stem bark of Balanites aegyptiaca Delile. Indian Journal of Chemistry 45:2154-2156.

Arbonnier M (2004) Trees, Shrubs and Lianas of West African Dry Zones. CIRAD, MARGRAF Publishers GMBH.

Aregay N , Hruy G , Semere T (2017) Potentials and Constraints of Under-Utilized Tree Fruits and Vegetables in Tigray, Northern Ethiopia - Journal of the Drylands 7: 664-674.

Augustus ND, Maalekuu BK, Akurugu GK (2014) Postharvest handling of the Edible Parts (Leaves and Fruits) of the Desert Date (Balanites aegyptiaca) A Case Study in the Jirapa and Nadowli Districts of the Upper West Region of Ghana. International journal of plant, animal and Environmental Sciences: 4: 573-583.

Barley S (1962) Zygophyllaceae. In: Watt JM, Breyer-Brandwijk MG (Eds.) The Medicinal and poisonous plants of Southern and Eastern Africa. London: Livingstone Ltd; 1962. Pp. 1064.

Beneytout JL, Nappez C, Leboutet MJ, Malivvand G (1995) A plant steroid, diosgenin a new megakaryocytic differentiation induce of HEL cell. Biochemical and Biophysical Research Communications 207:398-404.

Billore SKV (1988) Balanites aegyptiaca: A Browse Plant of High Protein Value in Degraded Lands. In: Singh P, Pathak PS (Eds.), Rangelands Resources and Management, Pp: 350-355.

Bobbo AA, Pukuma MS, Qadeer MA (2016) Assessment of Larvicidal Activity of Hyptis suaveolens and Balanites aegyptiaca Leaves and Root Extracts against Mosquito Species. International Journal of Scientific and Research Publications 6:10-14

Breimer L, ElSheikh SH, Furu P (2007) Preliminary investigation of the disposition of the molluscicidal saponin deltonin from Balanites aegyptiaca in a snail species (Biomphalaria glabrata) and in mice. Journal of Pesticide Science 32:213-221.

Bukar A, Danfillo I, Adeleke O, Ogunbodede E, (2004) Traditional oral health practices among Kanuri women of Borno state Nigeria. Odontostomatol Tropicale 27:25-31.

Campbell L, White J, Campbell R (1996) Acarbose: its role in the treatment of diabetes mellitus Annals of Pharmacotherapy 30: 1255-1262.
Chapagain BP, Hariv Y, Zeev W (2009) Desert date (Balanites aegyptiaca) as an arid lands sustainable bioresource for biodiesel. Bioresource Technology 100: 1221-1226.

Chaudhry T, Khoo C (2004) Balanites herbs potential remedy for HIV/AIDS and other ailments, vol. 47. Hamdard Medicus, Bait al-Hikmah, Karachi, Pakistan Pp. 42-44.

Chevallier MH, Bensaid S, Diallo OB, Sahki R, Ganaba S, Sanou J, Bouguedoura N, Vaillant A, Babin D (2003) Biodiversité et multidisciplinarité : méthodologie pour les zones arides. Bois et Forêts des Tropiques $276: 33-41$.

Chothani DL, Vaghasiya HU (2011) A review on Balanites aegyptiaca Del (desert date): phytochemical constituents, traditional uses, and pharmacological activity. Pharmacognosy Reviews $5:$ 55-62.

Cook JA, Vanderjagt DJ, Pastuszyn A, Mounkaïla G, Glew RS, Glew RH 1998 Nutrient content of two indigenous Plant foods of the werstern Sahel:Balanites aegyptiaca and Maerua crassifolia. Journal of Food Composition and Analysis 11: 221230.

Cordano G, Terrien M, Plonsky J, Rabanal R, Varenne P (1978) Balanitol, a new sesquiterpene from B. roxburghii, carbon-13 NMR analysis of eudesonancesesquiterpenoids. Journal of the Indian Chemical Society 55:1148-51.

Dawidar AAM, Fayez BE (1969) Steroid Sapogenins. XIII. The constituents of Balanites aegyptiaca. Phytochemistry 8:261-265.

Elfeel AA, Warrag EI (2011) Uses and conservation status of Balanites aegyptiaca (L.)Del. (Hegleig Tree) in Sudan: Local people perspective. Asian Journal of Agricultural Sciences $3: 386$ $-390$.

Elhardallou SB, Elawad AM, Khairi NA, Gobouri AA, Dhahawi HO (2014) A Review on Omega-3 and Omega-6 Essential Fatty Acids: Uses, Benefits and their Availability in Pumpkins (Cucurbita maxima) Seed and Desert Dates (Balanites aegyptiaca) Seed Kernel Oils. Pakistan Journal of Biological Sciences, 17: 1195-1208.

Elseed AMAF, Amin AE, Khadiga, Ali AA, Sekene J, Hishinum M, Hamana K (2002) Nutritive evaluation of some fodder tree species during the dry season in Central Sudan. AsianAustralasian Journal of Animal Sciences 15: 844-850.

FAO (1985) An all purpose tree for Africa offers food and income. Ceres 18: 6-7.

Farag M, Porzel A, Wessjohann L (2015) Unraveling the active hypoglycemic agent trigonelline in Balanites aegyptiaca date fruit 
using metabolite fingerprinting by NMR.

Journal of Pharmaceutical and Biomedical Analysis 115: 383-387.

Farid H, Haslinger E, Kunert O, Wegner C, Hamburger M (2002) New steroidal glycosides from Balanites aegyptiaca. Helvetica Chimica Acta 85:1019-1026.

Francis G, Kerem Z, Makkar H, Becker K (2007) The biological action of saponins in animal systems: a review. British Journal of Nutrition 88: 587-605.

Gad MZ, El-Sawalhi MM, Ismail MF, ElTanbouly ND (2006) Biochemical study of the anti-diabetic action of the Egyptian plants Fenugreek and Balanites. Molecular \& Cellular Biochemistry 281: 173-183.

Gnoula C, Mégalizzi V, De Nève N, Sauvage S, Ribaucour F, Guissou P, Duez P, Dubois J, Ingrassia L, Lefranc F, Kiss R, Mijatovic T (2008). Balanitin-6 and -7: diosgenyl saponins isolated from Balanites aegyptiaca Del. display significant antitumor activity in vitro and in vivo. International Journal of Oncology 32:5-15

Grosskinsky B, Gullick C (2001) Potential of indigenous food plants to support and strengthen livelioohs in Southern Sudan. In: Kenyatta C, Henderson A (Eds.), the potential of indigenous wild foods. Workshop proceedings, USAID/OFDA, Mombassa, Kenya.

Guinand Y, Lemessa D (2001) Wild food plants in Ethiopia: Reflections on the role of wild foods and famine foods at a time of drought. In: Kenyatta C, Henderson A (Eds), the potential of indigenous wild foods. Workshop proceedings, USAID/OFDA, Mombassa, Kenya.

Gupta SC, Shenoy S, Kotecha M (2012) Pharmacognostical and Phytochemical evaluation of Balanites aegyptica Del. Stem Bark. International Research Journal of Pharmacy 3: 169 -173.

Gutti B, Bamidele SS, Bagaje IM (2012) Characterization and composition of Balanites aegyptiaca seed oil and its potential as biodiesel feedstock in Nigeria. Journal of Applied Phytotechnology in Environmental Sanitation 1: 29-35.

Hall JB, Waljer DH (1991) School of Agricultural and Forest Science.Banger: University of Wales; 1991. Balanites aegyptiaca Del. A monograph; Pp. 1-12.

Hamid O, Wahab M, Hassan E (2001) Balanites aegyptiaca extract for treatment of HIV/ AIDS and leukemia. International Publication Number WO 2001/49306 A1.
Hammouda F, Ismail S, Abdel-Azim N, Shams K, Batanouny K (2005) A guide to medicinal plants in North Africa. IUCN Centre for Mediterranean Cooperation, Malaga, Spain, Pp. 77-78.

Hanan A, Al-Ashaal AF, Ayman MM, Abd El-Aziz, Ali MA (2009) Phytochemical investigation and medicinal evaluation of fixed oil of Balanites aegyptiaca fruits (Balantiaceae). Journal of Ethnopharmacology 2: 495-501.

Hardman R, Sofowora EA (1970) Isolation and characterization of yamogenin from Balanites aegyptiaca. Phytochemistry 9: 645649.

Hardman R, Sofowora EA (1972) A reinvestigation of Balanites aegyptiaca as a source of steroidal sapogenins. Economic Botany 26:169-173.

Hassan LE, Dahham SS, Saghir SA, Mohammed AM, Eltayeb NM, Majid AM, Majid AS (2016) Chemotherapeutic potentials of the stem bark of Balanite aegyptiaca (L.) Delile: an antiangiogenic, antitumor and antioxidant agent. BMC Complementary and Alternative Medicine 16:396.

Helal EGE, AbdEl-Wahab SM, El Refaey H, Mohammad AA (2013) Antidiabetic and Antihyperlipidemic Effect of Balanites aegyptiaca Seeds (Aqueous Extract) on Diabetic Rats. The Egyptian Journal of Hospital Medicine 52: 725-739.

Hosny M, Khalifa T, Calis I, Wright AD, Sticher O (1992) Balanitoside: A furostanol glycoside, and 6-methyldiosgenin from Balanites aegyptiaca. Phytochemistry. 31:3565-3569.

Hostettmann K, Marston A (1995) Saponins: chemistry and pharmacology of natural's products. Cambridge University Press, Cambridge, UK.

Hung W, Suh J, Wang Y (2016) Chemistry and health effects of furanocoumarins in grapefruit. Journal of Food and Drug Analysis 25: 71-83.

Kamel MS (1998): A Furostanol saponin from fruits of Balanites aegyptica. Phytochemistry 48 : 755-57

Kamel MS, Koskinen A (1995) Pregnane glycosides from fruits of Balanites aegyptiaca. Phytochemistry 40:1773-1775.

Kapseu C, Mbofung CMF, Kayem GJ (1997) Fatty acids and triglycerides of fruit oils from Cyperus esculentus and Balanites aegyptiaca. Sciences des Aliments 17:531-537.

Katewa SS, Chaudhary BL, Jain A (2004) Folk herbal medicines from tribal area of Rajasthan, India. Journal of Ethnopharmacology 92: 41-46. 
Khare CP (2007) Indian Medicinal Plants-An Illustrated Dictionary. 1st Indian Reprint Springer (India) Pvt. Ltd., New Delhi, India. 2007;28.

Koch A, Tamez P, Pezzuto J, Soejarto D (2005) Evaluation of plants used for anti malarial treatment by the Maasai of Kenya. Journal of Ethnopharmacology 101: 95-99.

Koko WS, Abdalla HS, Galal M, Khalid HS (2005) Evaluation of oral therapy on mansomal schistosomiasis using single dose of Balanites aegyptiaca fruits and praziquantel. Fitoterapia 76:30-4.

Koko WS, Galal M, Khalid HS (2000) Fasciolicidal efficacy of Albizia anthelmintica and Balanites aegyptiaca compared with albendazole. Journal of Ethnopharmacology 71:247-52.

Kommu S, Gowrishankar NL, Kamala D, Saritha B, Srinivasulu V, Naresh B, Sandeep K, Nagesp P (2013) Evaluation of Wound Healing Activity of Methanolic Extract of Balanites aegyptiaca L. Leaves. International Journal of Pharmacy and Pharmaceutical Sciences 5: 52-53.

Kumawat BK, Gupta M, Chand T, Singh Y (2012) Prelimenary phytochemical investigation on leaves of Balanites aegyptiaca (L.).Research Journal of Pharmaceutical, Biological and Chemical Sciences. $3: 0975-8585$.

Kusch P, Deininger S, Specht S, Maniako R, Haubrich S, Pommerening T, Lin PKT, Hoerauf A, Kaiser A (2011) In Vitro and In Vivo Antimalarial Activity Assays of Seeds from Balanites aegyptiaca: Compounds of the Extract Show Growth Inhibition and Activity against Plasmodial Aminopeptidase. Journal of Parasitology Research, Article ID 368692, 9 pages, 2011. https://doi.org/10.1155/2011/368692.

Locket CT, Calvert CC, Grivetti LE (2000) Energy and micronutrients composition of dietary and medicinal wild plants consumed during drought Study of rural Fulani, North easthern Nigeria. International Journal of Food Sciences 51: 195-208.

Maksoud S, El Hadidi M (1988) The flavonoids of Balanites aegyptiaca (Balanitaceae) from Egypt. Plant Systematics and Evolution 160: 153-158.

Mariam S, Onyenibe NS, Oyelola OB (2013) Aqueous Extract of Balanites aegyptiaca Del Fruit Mesocarp Protects against CCl4 Induced Liver Damage in Rats. British Journal of Pharmaceutical Research 3: 917-928.

McNeely W, Goa K (1998) 5-Methoxypsoralen. A review of its effects in psoriasis and vitiligo. Drugs 56: 667-690.

Mohamed AH, Eltahir KEH, Ali MB, Galal M, Ayeed IA, Adam SI, Hamid OA (1999) Some pharmacological and toxicological studies on Balanites aegyptiaca bark. Phytotherapy Research 13: $439-441$.

Molla E, Giday M, Erko B (2013) Laboratory assessment of the molluscicidal and cercariacidal activities of Balanites aegyptiaca. Asian Pacific Journal of Tropical Biomedicine 3 : 657-662.

Montasser AOS, Saleh H, Ahmed-Farid OA, Saad A, Marie MS (2017) Protective effects of Balanites aegyptiaca extract, Melatonin and Ursodeoxycholic acid against hepatotoxicity induced by Methotrexate in male rats. Asian Pacific Journal of Tropical Medicine 10: 557-565

Morsy AMA (2008) Environmental and biochemical assessment of some wild plants growing south of the eastern desert. Ph.D thesis submitted to the Department of Biochemistry, Faculty of Agricultural Science, Ain Shams University, Pp. 1-161.

Mostafa FAA, Ali AO, Elreffaei1 WHM, Shalaby RA, Mehanni AE (2016) Antibacterial and Antioxidant Activities of Balanites aegyptiaca Kernel and Its Effects on Cc14 Treated Rats. Mansoura Journal of Food and Dairy Sciences 7: 407 - 414.

Nappez C, Liagre B, Beneytout JL (1995) Changes in lipoxygenase activities in human erythroleukemia (HEL) cells during diosgenin induced differentiation. Cancer Letter 96:133140 .

Natinal Research Council (2008) Lost Crops of Africa: Volume III, Fruits, Development, Security and Cooperation. The National Academies Press, Washington, D.C.

Ndoye M, Diallo I, Gassama YK (2004) Reproductive biology in Balanites aegyptiaca(L.) Del., a semi-arid forest tree. African Journal of Biotechnology 3:40-46.

Neuwinger HD (1996) African Ethnobotony poisons and drugs, Champan and Hal, Londan, United Kingdom Pp. 941.

Obidah W, Nadro MS, Tiyafo GO, Wurochekke AU (2009) Toxicity of Crude Balanites aegyptiaca Seed Oil in Rats. The Journal of American Science 5:13-16.

Ojo O, Nadro M, Tella I (2006) Protection of rats by extracts of some common Nigerian trees against acetaminophen-induced hepatotoxicity. African Journal of Biotechnology 5:755-760.

Okia CA, Agea JG, Kimondo JM, Abohassan RAA, Okiror P, Obua J, Teklehaimanot Z (2011) Use and Management of Balanites aegyptiaca in Drylands of Uganda. Research Journal of Biological Sciences 6: 15-24.

Pandey CN (2005) Gujarat, India: Gujarat Ecological Education and Research Foundation, Medicinal plants of Gujarat; Pp. 387. 
Patil SV, Salunke BK, Patil CD, Salunkhe RB, Gavit P, Maheshwari VL (2010) Potential of extracts of the tropical plant Balanites aegyptiaca (L) Del.(2010): (Balanitaceae) to control the mealy bug, Maconellicoccus hirsutus (Homoptera: Pseudococcidae). Crop Protection 29: 1293 - 1296.

Pettit GR, Doubek DL, Herald DL, Numata A, Takahasi C, Fujiki R, Miyamoto T (1991) Isolation and structure of cytostatic steroidal saponins from the African medicinal plant Balanites aegyptiaca. Journal of Natural Product 54:1491-502.

Rao MV, Shah KD, Rajani M (1997) Contraceptive efficacy of Balanites roxburghii pericarpium extract in male mice (Mus musculus). Phytotherapy Research 11:469 - 471.

Rathore M, Arya R, Meena RK, Kumar H (2005) Shuahk kshetro mei paye jane wale tailiya beejo ke vrikshon ki sambhavit upigoyita. AFRI Darpan (Hindi) 2:12-13.

Rice-Evans C, Miller N, Paganga G, (1996) Structure-antioxidant activity relationships of flavonoids and phenolic acids. Free Radical Biology and Medicine 20: 933-956.

Rohini K, Srikumar PS (2014) Therapeutic Role of Coumarins and Coumarin-Related Compounds. Journal of Thermodynamics \& Catalysis 5: 130. DOI: 10.4172/2157-7544.1000130.

Saeed A, Ibrahim N, Bashandy S, El-Gengaihi S (1995) Saponin of Balanites aegyptiaca Del fruits and biological evaluation. Bulletin of Faculty of Pharmacy, Cairo University 33:105-9.

Saharan V, Yadav R, Wiesman Z (2008) Balanites aegyptiaca (L.) Delile: A potential source of saponin. Current Biotica 2: 110-113.

Salwa A, Maksoud, Hadidi MNE (1988) The flavonoids of Balanites aegyptiaca (Balanitaceae) from Egypt. Plant Systematics and Evolution 3-4: 153-158.

Samuelsson G, Farah MH, Claeson P (1991) Inventory of plants used in traditional medicine of somania, plant of the families Acanthaceae- Chenopodiaceae. Journal of Ethanopharmacology $35: 25-30$.

Sarker S, Bartholomew B, Nash R (2000) Alkaloids from Balanites aegyptiaca. Fitoterapia 71 :328-30. doi: 10.1016/S0367-326X(99)00149-5.

Seida AA, Kinghorn AD, Cordell GA, Farnsworth NR (1981) Isolation of bergapten and marmesin from Balanites aegyptiaca. Planta medica 43: 92-93.

Shalaby H, El Namaky A, Khalil F, Kandil O (2012) Efficacy of methanolic extract of Balanites aegyptiaca fruits on Toxocaravitulorum. Veterinary Parasitology 183: 386-392.
Sheded MG, Pulford ID, Hamed AI (2006) Presence of major and trace elements in seven medicinal plants growing in the SouthEastern Desert, Egypt. Journal of Arid Environment 66: 210-217.

Sibhat GG, Hiben MG (2016) Consequence of concurrent use of chloroquine and hydroalcoholic extract of Balanites aegyptiaca and leaf leatx of Aloe camperi. The Journal of Phytopharmacology 5: 35-37.

Sourabie TS, Kinda D, Yaro B, Nikiema JB (2013) Ethnobotanical Survey of Medicinal Plants Used By the Traditional Medical Healers in the Villages of Bérégadougou and Fabédougou (Cascades Region, Burkina Faso) - Balanites aegyptiaca Balanitaceae Tree Fruit . IOSR Journal of Pharmacy 3: 38-45.

Spencer J (2008) Flavonoids: modulators of brain function? British Journal of Nutrition 99: ES60-ES77.

Speroni E, Cervellati R, Innocenti G, Costa S, Guerra M, Dall S (2005) Anti-inflammatory, anti-nociceptive and antioxidant activities of Balanites aegyptiaca (L.) Delile. Journal of Ethnopharmacology 98:117-25.

Stadlmayr B, Charrondière U, Eisenwagen S, Jamnadass R, Kehlenbeck K (2013) Nutrient composition of selected indigenous fruits from sub-Saharan Africa. Journal of the Science of Food and Agriculture 93: 2627-2636.

Staerk D, Chapagain BP, Lindin T, Wiesman Z, Jaroszewski JW (2006) Structural analysis of complex saponins of Balanites aegyptiaca by $800 \mathrm{MHz}$ 1H NMR spectroscopy. Magnetic Resonance in Chemistry 44: 923-928.

Suky TMG, Parthipan B, Kingston C, Mohan VR (2011) AntiInflammatory Activity of Aerial part of Balanites aegyptiaca (L.) Del against Carrageenan induced Paw Oedema. International Journal of PharmTech Research 3: 639-643.

Thirupathi K, Krishna DR, Ravi Kumar B, Tirumala Rao P, Krishna Mohan G (2009) Anticonvulsant Activity of Pericarpium Extract of Balanites Roxburghii Planch in Mice. Pharmacologyonline 1: 1150-1157.

Varshncy IP, Vyas P (1982) Saponin and Sapogenin contents of Balanites roxburghii. International Journal of Crude Drug Research 20:3-6.

Wabale AS (2017) Crucial and Effective Ethnomedicinal Plants in Treating Boils and Burns. Advances in Bioresearch 8: 73-74.

Wani N, Kabade J, Kabade M, Joshi S, Patil A (2010) Diuretic activity of leaves of Balanites Roxburghii Linn. International Journal of Pharmaceutical Research and Development 2: 4. 
Wiesman Z, Chapagain BP (2003) Laboratory evaluation of natural saponin as a bioactive agent against Aedes aegypti and Culex pipiens. Dengue Bulletin 27:168-173.

Wiesman Z, Chapagain BP (2006) Larvacidal activity of saponin containing extracts and fractions of fruits mesocarp of Balanites aegyptiaca, Fitoterapia 77:420-424.

Wilt T, Ishani A, MacDonald R, Stark G, Mulrow C, Lau J (1999) Beta-sitosterols for benign prostatic hyperplasia. Cochrane Database of Systematic Reviews CD001043.

Wufem BM, Adamu HM, Cham YA, Kela SL (2007) Preliminary studies on the antivenin potential and phytochemical analysis of the crude extracts of Balanites aegyptiaca (Linn.) Delile on albino rats. Natural Product Radiance 6:18-21.

Wurochekke AU, Nok AJ (2004) In vitro anti trypanosomal activity of some medicinal plants used in the treatment of trypanosomosis in Northern Nigeria. African Journal of
Biotechnology $3: 481-483$.

Yabe-Nishimura C (1998) Aldose reductase in glucose toxicity: a potential target for the prevention of diabetic complications. Pharmacological Reviews 50: 21-34.

Yadav JP, Panghal M (2010) Balanites aegyptiaca (L.) Del. (Hingot): A review of its traditional uses, phytochemistry and pharmacological properties. International Journal of Green Pharmacy 4: 140-6.

Zaahkouk SAM, Aboul-Ela EI, Ramadan MA, Bakry S, Mhany ABM (2015) Anti carcinogenic activity of Methanolic Extract of Balanites aegyptiaca against breast, colon, and liver cancer cells. International Journal of Advance Research 3:255-266.

Zang CU, Jock AA, Garba IH , Chindo, IY (2017) Physicochemical and Phytochemical Characterization of Seed Kernel oil From Desert Date (Balanites aegyptiaca). Journal of Chemical Engineering and Bioanalytical Chemistry 2: 49-61. 